\title{
Plutonium Isotopic Analysis of Highly Enriched Mixed Oxides
}

S. D. Clement

R. H. Augustson 


\section{CONTENTS}

ABSTRACT . . . . . . . . . . . . . . . . . . 1

$\because \quad$ INTRODUCTION . . . . . . . . . . . . . . . . . 2

II. THEORY . . . . . . . . . . . . . . . . 3

III. EXPERIMENT . . . . . . . . . . . . . . . . . . 4

A. Equipment . . . . . . . . . . . . . 6

B. Procedure .. . . . . . . . . . . . 6

IV. RESULTS . . . . . . . . . . . ...... 7

V. ANALYSIS OF RESULTS . . . . . . . . . . . . . . II

REFERENCES . . . . . . . . . . . . . . . . . . 15

APPENDIX. DATA COLlection PARAMETERS . . . . . . . . 15 
PLUT'ONIUM ISOTOPIC ANALYSIS OF HIGHLY ENRICHED MIXED OXIDES

by

S. D. Clement and R. H. Augustson

\begin{abstract}
We investigated the analysis method used by the International Atonic Energy Agency (IAEA) to determine the plutonium isotopic composition of highly enriched mixed oxides (MOX). The IAEA currently uses the Cicero multichannel analyzer and the IAEAPU algorithm for its analysis. In our investigation the plutontum isotopic measurements were found to be good for $\mathrm{PuO}_{2}$ powder or low-enriched HOX, but unacceptable for highly enriched MOX in IAEA special nuclear material (SNM) accountability applications. The gamma-ray interferences from ${ }^{235} \mathrm{v}$ resulted in underestimation of the isotopic composition $\mathrm{wi}{ }^{239} \mathrm{pu}$ and overestimation of all other plutonium isotopes. Samples with high ${ }^{240}$ pu content were found to have significantly higher error in plutonium ssotopic analyses of highly enriched mox. Code modifications or use of calibration curves are necessary for plutoniun isotopic analyses of highly enriched MOX in IAEA SNM accountability applications.
\end{abstract}


I. INTRODUCTION

Concern about the spread of nuclear weapons has brought attention to the need for widespread nuclear materials accountability. The responsibility at the international level lies with the International Atomic Energy Agency (IAEA). The IAEA is responsible for nuclear materials accountability for those countries that have signed the Nuclear Non-Proliferation Treaty and therefore fall under the realm of IAEA safeguards. The primary goal of the IAEA is to detect the theft or diversion of special nuclear materials (SMM) for possible use in weapons programs or terrorist activities.

Nuclear materials accountability has been revolutionized by the use of nondestructive assay (NDA) techniques. These techniques allow the contenis of an SNM package to be analyzed for material type, quantity, and isotopic abundance without breeching the container and disturbing the sample. Implementation of safeguards instrumentation therefore does not require modification to existing facility hardware but simple addition of equipment. SNM identification comes from analysis of radiation produced by the materials. Fctive and passive neutron colncidence ccunting provide us with the quantity of material, and high-resolution gamma-ray spectrometry provides us with the isotopic composition.

Different NDA techniques are used for different materials. In mcst situations, both neutron and gamma-ray assays must be combined to yield the required information for SMM accountability. For example, to quantitatively measure plutonium by nondestructive techniques requires high-level neutron coincidence counting or calorimetry and plutonium isotopic abundance measurements. This approach has been developed into a field-usable system for the IAEA ${ }^{1.2}$ [and implemented in the cicero multichannel analyzer (MCA)] by Lawrence Livermore National Laboratory.

This investigation was conducted to examine the effects of highly eiriched mixed oxides (MOX) on measured plutonium isotopic compositions. This report explains the calculational method for determining the isotopics, describes the experiment, discusses the results, and makes recommendations concerning the analysis. 
II. THEORY

High-resoluti: . jamma-ray spectrometry measurements are made on bulk plutonium samples to ietermine their 1sotopic abundances. The isotopic ratics are calculated from gamma-ray peaks in the 110- to 400-keV region. The general method for calculating these ratios is based on the following equation:

$$
\frac{N_{1}}{N_{j}}=\frac{I_{1} B_{1} \varepsilon_{1} t_{1}}{I_{j} B_{j} \varepsilon_{j} t_{j}} \text {. }
$$

where $N_{1} / N_{j}=$ atom ratios of 1sotopes 1 and $f$.

$I=$ observed peak intensity.

$B=$ gamma-ray branching intensity.

$\varepsilon=$ detector efficiency. and

$t=$ half-life.

The half-life and branching intensity are known values, whereas the detector efficlency is a function of energy. The influence of efflclency is minimized by using gamna-ray peaks that are nearly equal in energy. Nelghboring peaks of known relative intensities are used to establish a calibration curve and correct for the small energy differences.

Accurate final results are dependent upon precise peak-intensity measurements. This requires proper delineation of peak shape, accurate background measurements, and methods for unfolding peak multiplets. The equation describing the peak shape consists of a Gaussian distribution function and a shortterm talling function:

$$
Y_{1}=Y_{0} e^{a\left(X_{1}-X_{0}\right)^{2}}+A Y_{0} e^{B\left(X_{1}-X_{0}\right)}\left[1-e^{C_{a}\left(X_{1}-X_{0}\right)^{2}}\right]_{\delta} .
$$


where

$$
\begin{aligned}
\mathrm{Y}_{1} & =\text { net data counts at } 1, \\
\mathrm{y}_{0} & =\text { peak height, } \\
\alpha & =\text { peak width parameter }, \\
x_{1} & =\text { channel value at } 1 . \\
x_{0} & =\text { channel value at the peak centrold, }
\end{aligned}
$$

A. B, C = shape parameters, and

$$
\delta=1 \text { for }{ }_{1}-x_{0}<0 ; 0 \text { for } x_{1}-x_{0}>0 \text {. }
$$

All peak parameters a! ? determined from the 148.6-kev peak of ${ }^{241} \mathrm{Pu}$ and the 208.0-kev peak of ${ }^{237_{\mathrm{U}}}$ The only remaining parameter needed to describe the peak shape is the feak height. The equation then becomes linear in form and can be solved by a linear least-squares method.

The background beneath the peak must be removed before the net peak area can be determined. The following function is used to produce smoothed background steps at each peak position.

$$
B_{i}=b_{n}+\left(b_{m}-b_{n}\right) \sum_{j=n}^{j=i} y_{j} / \sum_{k=n}^{k=m} y_{k},
$$

where $B_{i}=$ computed background at $i$,

$Y_{1}=$ spectrum count of channel $i$,

$b_{n}=$ average low-energy background, and

$b_{m}=$ average high-energy background.

The background at channe $i\left(B_{i}\right)$ can then be subtracted from the spectrum count of channel $1\left(Y_{i}\right)$ to get the net counts.

\section{III . EXPER IMENT}

The algorithm IAEAPU is designed to return the isotopic analysis of pure plutonium samples that have no interferences from other radioactive materials. With the presence of other radioactive materials that emit gamma rays similar 
In energy to those of plutonium, interferences can occur. Consequently, the results of the isotopic analysis will be changed because of the additional gamma rays. This situation is precisely what happens when an oxide containing both uranium and plutonium is analyzed by the cicero. Uranium-235 gamma rays interfere with plutonium gamma rays and produce erroneous results. Figure 1 illustrates some of the Interferences produced when a Mox sample is analyzed.

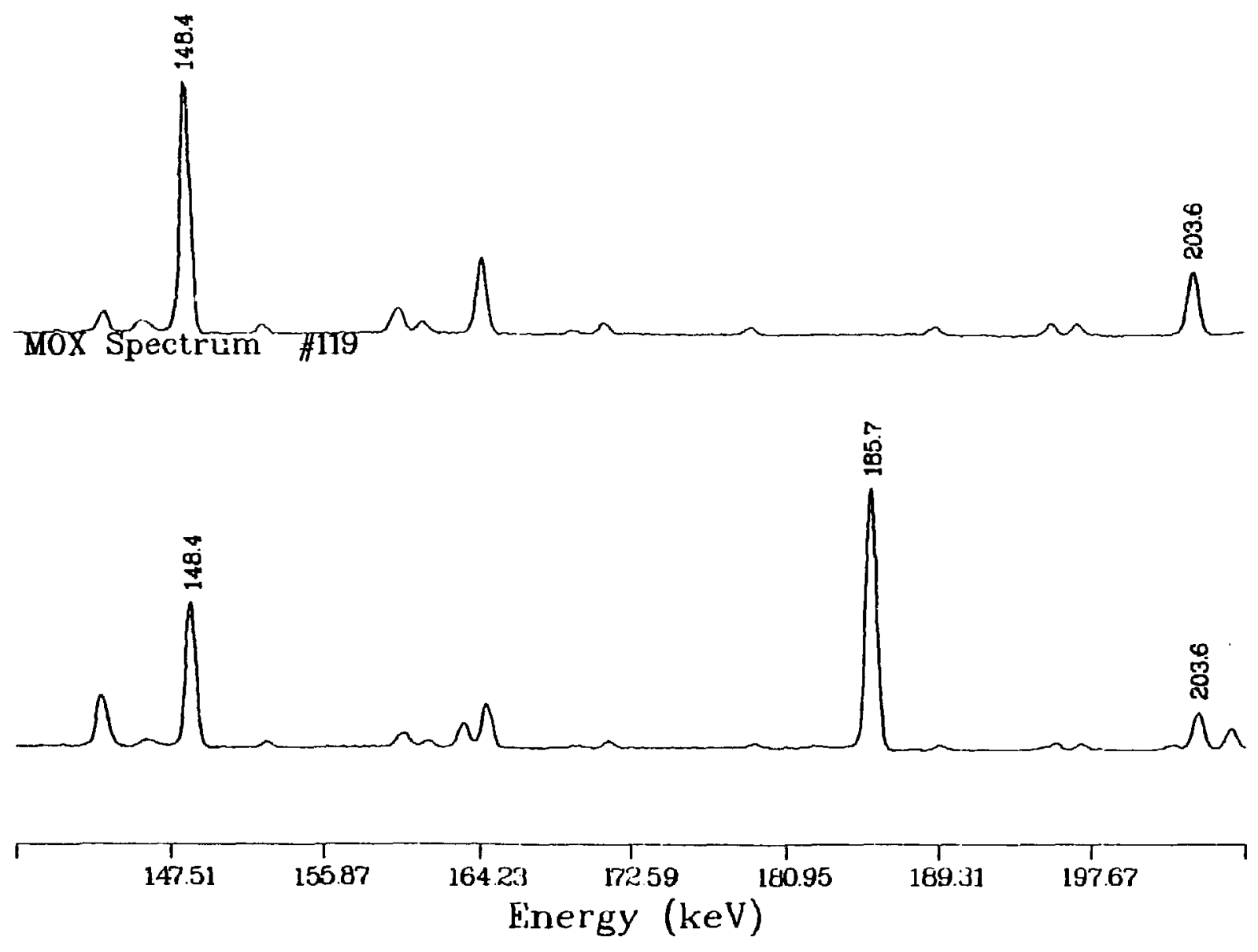

Fig. 1. Mixed-oxide and $\mathrm{PuO}_{2}$ spectra.

The experiment consisted of studying the effect of ${ }^{235} \mathrm{U}$ interferences that occur in mox samples. Because of the unavailability of highly enriched mox for measurement, a scheme was developed to simulate mox samples from pure $\mathrm{PuO}_{2}$ powder and high-enriched uranium (fIEU) folls. 
A. Equipment

An intrinsic germanium detector was used for the high-resolution spectrometry. The output signal was fed to the Cicero 8-k MCA. The plutonium 1sotopic analysis unit built into the cicero MCA examines the spectra and performs the calculations. The algorithm will best fit the peaks with the most channels. It is therefore desirable to have the highest gain possible. Table I lists the plutonium and uranium samples used to simulate the mox; the Cicero data collection parameters are presented in the Appendix.

\section{B. Procedure}

The plutonium sample was first measured for $2000 \mathrm{~s}$ and a data analysis was performed. The HEU sample spectrum was then collected for $100 \mathrm{~s}$, overlaying the plutonium spectrum, and the data analysis was repeated. The uranium samples were counted and analyzed in 100-s increments until a ${ }^{235} \mathrm{U} /{ }^{239} \mathrm{Pu}$ value of approximately 10 was reached.

\section{TABLE I}

$\mathrm{PUO}_{2}$ AND URANIUM SAMPLES

\begin{tabular}{|c|c|c|c|c|c|c|c|c|}
\hline \multirow{2}{*}{$\begin{array}{l}\text { Sample } \\
\text { No. }\end{array}$} & \multirow[b]{2}{*}{ Material } & \multirow{2}{*}{$\begin{array}{l}\text { Mass } \\
(g)\end{array}$} & \multirow{2}{*}{$\begin{array}{l}\text { Enr ichunent } \\
(q)\end{array}$} & \multicolumn{5}{|c|}{ Isotopic Abundances } \\
\hline & & & & ${ }^{238} \mathrm{pu}$ & $239 \mathrm{Pu}$ & $240_{\mathrm{Pu}}$ & $241_{\mathrm{Pu}}$ & ${ }^{242} \mathrm{Pu}$ \\
\hline 118 & $\mathrm{PuO}_{2}$ & 1.809 & - & 0.028 & 90.12 & 8.98 & 0.758 & 0.104 \\
\hline 119 & $\mathrm{PuO}_{2}$ & 1.722 & - & 0.04 & 86.87 & 11.74 & 1.17 & 0.167 \\
\hline 116 & $\mathrm{PuO}_{2}$ & 1.9002 & - & 0.384 & 78.33 & 15.18 & 5.08 & 1.03 \\
\hline 120 & $\mathrm{PuO}_{2}$ & 2.0307 & - & 0.384 & 78.33 & 15.18 & 5.08 & 1.03 \\
\hline 121 & $\mathrm{PuO}_{2}$ & -3 & - & 0.0628 & 81.712 & 16.442 & 1.432 & 0.352 \\
\hline 46 & $\mathbf{U}$ & 0.387 & 93.15 & - & - & - & - & - \\
\hline 77 & $\mathbf{U}$ & 0.468 & 93.0 & - & - & - & - & - \\
\hline 80 & $\mathbf{U}$ & 0.440 & 93.0 & - & - & - & - & - \\
\hline
\end{tabular}


IV. RESULTS

The cicero plutonium 1sotopic analysis unit utilizes 37 separate gamma rays grouped into nine regions. Table II lists the gamma rays by energy and gives the corresponding isotope and region. The peak areas are calculated once $\mathrm{Eq}$. (2) has been fit to the peaks and the background has been removed. The peak areas are displayed in the analysis output along with the gain, channel-zero energy, resolution, and 1sotopic ratios. An example of the cicero output is illustrated in Fig. 2. Note that the algorithm calculates the ${ }^{235} \mathrm{v} /{ }^{239} \mathrm{Pu}$ ratio.

TABLE II

ANALYZED GAMIA RAYS WITH CORRESPONDING ISOTOPES

Garma Energy

( $\mathrm{keV}$ )

122.92

123.61

124.50

125.20

125.29

129.29

141.56

144.21

146.07

146.55

148.56

150.10

152.67

154.19
Isotope

Region

${ }^{241}$ Am

${ }^{239} \mathrm{Pu}$

${ }^{239} \mathrm{Pu}$

${ }^{239} \mathrm{Pu}$

241 Am

${ }^{239} \mathrm{Pu}$

${ }^{239} \mathrm{Pu}$

$239 \mathrm{Pu}$

${ }^{239} \mathrm{Pu}$

${ }^{241}$ Am

${ }^{241} \mathrm{Pu}$

${ }^{241}$ Am

${ }^{238} \mathrm{Pu}$

sum
I

I

I

I

I

I

II

II

II

II

II

II

III

III 
TABLE II (cont)

\section{Gamma Energy}

(keV)

Isotope

Region

159.95

${ }^{241} \mathrm{Pu}$

239 Pu

$240 \mathrm{Pu}$

239 Pu

$237 \mathrm{U}$

241 Am

IV

160.18

160.30

161.48

164.59

165.93

185.72

$235 \mathrm{U}$

v

203.53

${ }^{239} \mathrm{Pu}$

VI

207.99

$237 \mathrm{U}^{241} \mathrm{Am}$

VII

322.38

237 U- $241_{\text {AIn }}$

$239 \mathrm{Pu}$

237 U- $241_{\text {Arn }}$

$239 \mathrm{Pu}$

239 Pu

${ }^{239} \mathrm{Pu}$

IV

IV

IV

IV

IV

332.84

335.42

336.10

341.51

345.01

367.04

368.54

368.60

370.93

375.04

376.59

380.16

382.74

${ }^{239}$

${ }^{239} \mathrm{Pu}$

241 Am

241 Am

${ }^{239} \mathrm{Pu}$

241 Am

${ }^{239} \mathrm{Pu}$

${ }^{239} \mathrm{Pu}$

VIII

VIII

VIII

VIII

VIII

VIII

IX

IX

IX

IX

IX

IX

IX

IX 
10:28 $\quad 8 / 2 / 82$

Spec \# 3; LT $=2000 \mathrm{~S}$

Gain $=0.1145 \mathrm{keV} / \mathrm{CH}$

CHNL zero E = 113.955

FWHM $(208 \mathrm{keV})=0.907$
Peak en Counts \%ER

$\begin{array}{lll}185.72 & 0 . & 60.1\end{array}$

Peak on Counts \%ER

$203.54 \quad 6927 . \quad 1.5$

Peak en Counts \%ER

$\begin{array}{lll}208.00 & 439530 . & 0.2\end{array}$

$\begin{array}{lrc}\text { Peak en } & \text { Counts } & \text { \%ER } \\ 122.92 & 20323 . & 0.9 \\ 123.61 & 288 . & \text { FIXD } \\ 124.50 & 910 . & \text { FIXD } \\ 125.21 & 848 . & \text { FIXD } \\ 125.29 & 78873 . & 0.4 \\ 129.29 & 92923 . & 0.4\end{array}$

Peak en Counts \%ER

1.41 .57 204. 46.3

$141.21 \quad 4428.2 .5$

146.08 1869. FIXD

$146.56 \quad 9738 . \quad 1.5$

$148.56 \quad 191185 . \quad 0.2$

150.11 1577. FIXD

$\begin{array}{rrr}\text { Peak en } & \text { Counts } & \text { \%ER } \\ 152.68 & 14428 . & 1.4 \\ i 54.20 & 0 . & 52.0\end{array}$

$\begin{array}{lrc}\text { Peak en. } & \text { Counts } & \text { \%ER } \\ 159.96 & 6037 . & \text { FIXD } \\ 160.20 & 86 . & \text { FIXD } \\ 160.29 & 5965 . & 2.3 \\ 161.45 & 1672 . & 5.7 \\ 164.58 & 46304 . & 0.5 \\ 165.93 & 347 . & 25.5\end{array}$
238PU/239PU $=0.003577$

$+-0.000075$

$240 \mathrm{PU} / 239 \mathrm{PU}=0.263086$

$+-0.007487$

$241 P U / 239 P U=0.038897$

$+-0.000576$

$241 \mathrm{AM} / 241 \mathrm{PU}=0.619975$

$+-0.010919$

$235 \mathrm{U} / 239 \mathrm{PU}=0.000000$

$+-0.000000$

Time since Sep =

3671.+- 52. days

$\% 238=0.272+-0.006$

$\% 239=75.933+-0.442$

$\% 240=19.977+-0.580$

$\% 241=2.954+-0.47$

$\% 242=0.864$ CALC

$\% A M / P U=1.831+-0.43$

Fig. 2, Sample Cicero output.

$\mathrm{HEU}$ foils were counted on top of each $\mathrm{PuO}_{2}$ spectra in 100-s increments with the isotopic analyses being repeated after each increment. As the uranium count time increased, the enrichment of the sinulated mox increased. For each additionai $100-\mathrm{s}$ uranium count, a linear increase in the ${ }^{235} \mathrm{U} /{ }^{239} \mathrm{Pu}$ ratio was observed. With the the increase in enrichment, the calculated isotopic error relative to the declared isotopics (see Table I) increased. 
The ${ }^{238} \mathrm{Pu},{ }^{240} \mathrm{Pu}$, and ${ }^{241} \mathrm{Pu}$ concentrations in each sample were well calculated at low ${ }^{235} \mathrm{U} /{ }^{239} \mathrm{Pu}$ values. However, with increased values of ${ }^{235} \mathrm{U} /{ }^{239} \mathrm{Pu}$, the calculated fractional content of each isotope became increasingly overpredicted. The relative error vs ${ }^{235} \mathrm{U} /{ }^{239} \mathrm{Pu}$ ratio for ${ }^{238} \mathrm{Pu},{ }^{240} \mathrm{Pu}$, and ${ }^{241} \mathrm{Pu}$ is illustrated in Figs. 3 to 5, respectively. In each case, the magnitude of the error is highest for the samples with the highest ${ }^{240} \mathrm{Pu}$ content.

Figure 6 illustrates the relative error vs ${ }^{235} \mathrm{v} /{ }^{239} \mathrm{pu}$ ratio for ${ }^{239} \mathrm{Pu}$. This fissile isotope is especially significant in IAEA SNM accountability

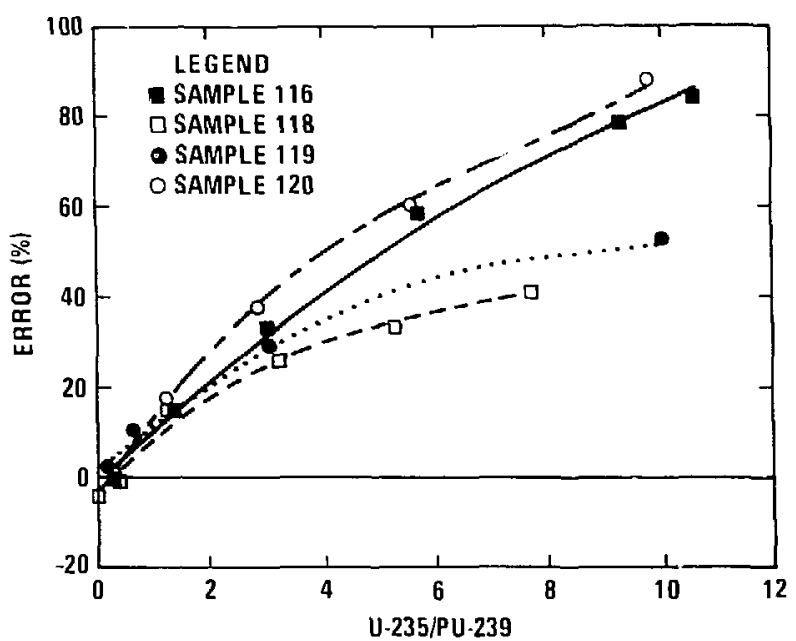

Fig. 3. Relative error for $238_{\mathrm{Pu}}$.

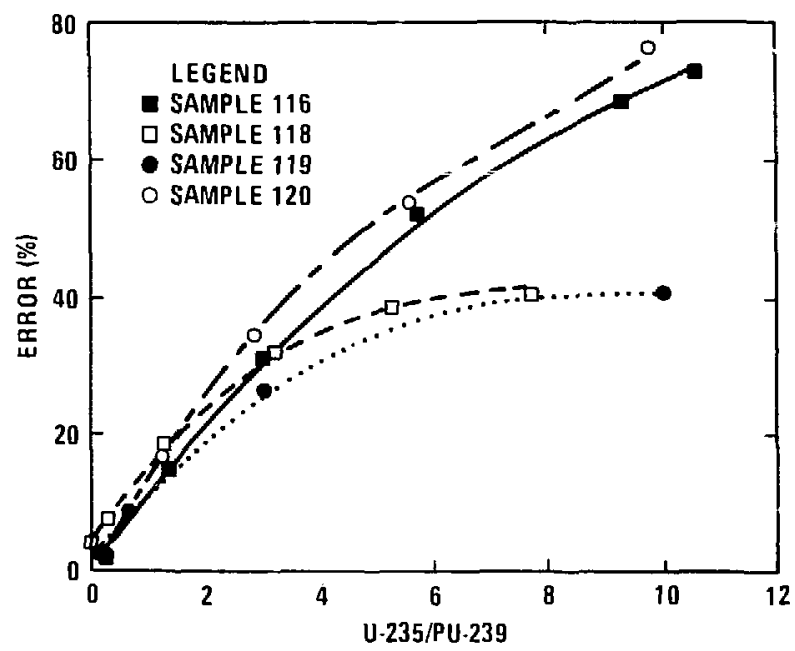

Fig. 5. Relative error for $24 l_{\mathrm{Pu}}$.

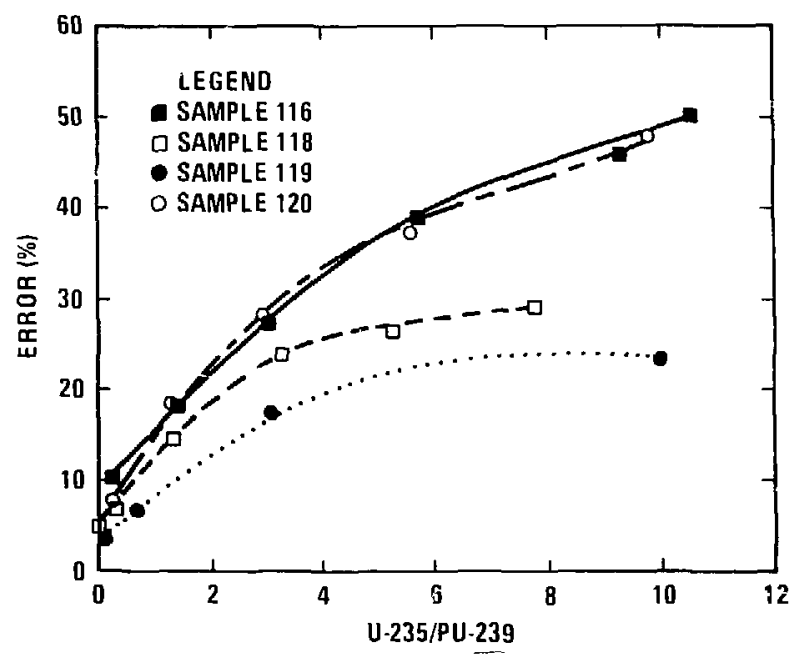

Fig. 4. Relative error for $240 \mathrm{Pu}$.

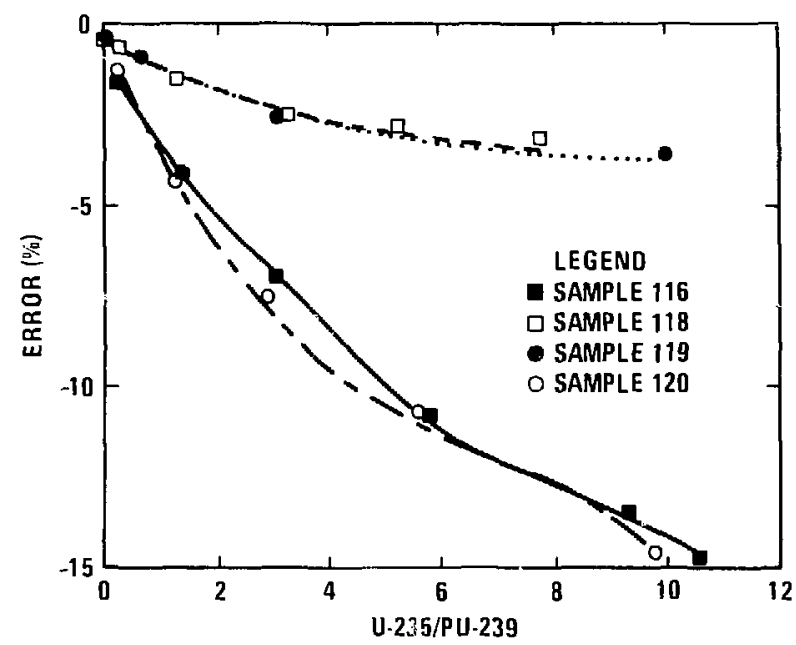

Fig. 6. Relative error for ${ }^{239} \mathrm{Pu}$. 
applications. The figure shows that the ${ }^{239} \mathrm{Pu}$ content is increasingly underpredicted as the ${ }^{235} \mathrm{v} /{ }^{239} \mathrm{Pu}$ ratio increases. Again, as with the previous isotopes, the magnitude of the error is largest in those samples with the largest ${ }^{240}$ pu content.

The relative error for ${ }^{242} \mathrm{Pu}$ (Fig. 7) is slightly different than that exhtbited by the other isotopes. For the other 1sotopes, as Figs. 3 ;0 6 show, the magnitude of the relative errors begins to saturate with increased values of ${ }^{235} \mathrm{u} /{ }^{239} \mathrm{Pu}$. The error for ${ }^{242} \mathrm{pu}$ is better represented as linear. The lack of this situration effect is due to the uncertainty of the ${ }^{241} \mathrm{Fu}$ isotopic concentration. Therefore, the ${ }^{241} \mathrm{Pu}$ isotopic concentration must be corrected for decay since the time of removal of the isotope from the reactor. However, in many cases the removal date is unknown. The ${ }^{242} \mathrm{Pu}$ isotopic concentration is calculated from the following correlation:

$$
(242)=\frac{k(240)(241)}{(239)^{2}}
$$

The magnitude of the error for the isotope ${ }^{242} \mathrm{Pu}$ at a given ${ }^{235} \mathrm{U} /{ }^{239} \mathrm{Pu}$ value is greater than that of any of the other isotopes.

\section{ANALYSIS OF RESULTS}

The plutonium isotopic composition measurements made by the Cicero MCA and analyzed by the algorithm IAEAPU produced good results for pure PuO, powder samples. The results are, in fact, excellent for ${ }^{238} \mathrm{Pu},{ }^{239} \mathrm{Pu},{ }^{240} \mathrm{Pu}$, and ${ }^{241} \mathrm{Pu}$, being within a few per cent; the results for ${ }^{242} \mathrm{Pu}$ are moderate, being 
off by up to 15\%. The results indicate that the IAEA would benefit by using this analysis method for SNM accountability of pure $\mathrm{PuO}_{2}$ samples.

uranium peaks can interfere directly with plutonium peaks or with backgrouna segtons of one of the nine peak groups. Direct interference with a peak will make the peak contain a larger number of counts so that the results of the computer analysis will exhibit a higher concentration in the isotope corresponding to the peak interfered with. This effect in turn will cause the remaining 1sotopes to be underpredicted because the sum of the 1sotoplc Eractions must equal 1.0. Interference peaks that occur in the background regions will produce lower 1sotopic compositions for each lsotope having a peak in the region. Background interferences increase the background counts, which are subtracted from the peak areas in the group. The additional reduction in peak areas makes the affected 1sotopes appear to have smaller abundances, and the remalning 1sotopes appear to have larger abundances than they really have. The larger the interference peak, the larger the error in the isotopic measurement.

The 1sotopic analysis uses peaks that range from 110 to $400 \mathrm{keV}$. Any urantum ganma rays that have energies out of this range can immediately be 1gnored. Uranium-238 has only four gamma rays between these energles; none of the four directly interfere with the plutonium peaks or any of the background regions. We can therefore conclude that ${ }^{238} \mathrm{U}$ does not interfere with plutonium isotopic measurements. Figures 3 to 7 illustrate that at $\log ^{235} \mathrm{U}^{239} \mathrm{Pu}$ ratios where virtualiy all of the uranium in the Mox is ${ }^{238} \mathrm{U}$, che error is very small. We can conclude from figs. 3 to 7 that all interferences must be from ${ }^{235} \mathrm{u}$ because as the ${ }^{235} \mathrm{u} /{ }^{239} \mathrm{Pu}$ ratio increases, the error increases.

sixteen ${ }^{235} \mathrm{U}$ gamma rays are present in the $110-$ to $400-k e V$ region. The most prominent gamma ray is at $185.7 \mathrm{keV}$ (see the Mox spectra of Fig. 1). of the sixteen ${ }^{235} \mathrm{v}$ gamma rays, five significantly interfere with the plutonium spectra; Table III lists these gamma rays and their interferences. The first Interference is at $140.75 \mathrm{keV}$; this gamm-ray lies in the low-energy background region of group 2. The branching ratio is smal1, therefore the impact of the Interference is small. The next interference occurs at $143.77 \mathrm{keV}$; this gamma ray directly interferss with the $144.21-\mathrm{keV}{ }^{239}$ Pu peak of group 2 . The effect of this interference on plutontum isotoplc measurements would be to increase the calculated 1sotoplc composition of ${ }^{239} \mathrm{Pu}$, whereas the $140.75-\mathrm{keV}$ low-energy backgrourd interference would tend to decrease the isotopic composition of any isotopes having peaks in group 2 . The next interference is the 


\begin{tabular}{llcc}
$\begin{array}{c}235 \mathrm{U} \\
\begin{array}{c}\text { Gamma-Ray } \\
\text { Energy } \\
(\mathrm{keV})\end{array}\end{array}$ & $\begin{array}{c}\text { Branching } \\
\text { Intensity }\end{array}$ & $\begin{array}{c}\text { Plutonium } \\
\text { Gamma-Ray } \\
\text { Interference } \\
(\mathrm{keV})\end{array}$ & Isotope Peal: \\
140.75 & 0.00208 & LEB & - \\
143.77 & 0.107 & 144.21 & $239 \mathrm{Pu}$ \\
163.37 & 0.0485 & 164.59 & $237 \mathrm{U}-{ }^{241} \mathrm{Am}$ \\
202.1 & 0.0107 & LEB & - \\
205.33 & 0.0487 & HEB & - \\
205.33 & 0.0487 & LEB & - \\
\hline aLEB stands for iow-energy background; HEB, for high-energy background.
\end{tabular}

164.59-keV peak of ${ }^{237} \mathrm{U}_{\mathrm{U}}{ }^{241} \mathrm{Am}$ in group 4. Both ${ }^{237} \mathrm{U}$ and ${ }^{241} \mathrm{Am}$ are decay products of ${ }^{241} \mathrm{Pu}$. The ${ }^{237} \mathrm{U}-{ }^{241} \mathrm{Am}$ peaks are sometimes used to determine the ${ }^{241} \mathrm{Pu}$ isotopic composition. Again, with the direct interference, the isotopic composition of ${ }^{241} \mathrm{pu}$ increases. Group 6 consists of one peak, a ${ }^{239}$ pu gamma ray at $203.53 \mathrm{keV}$. This single peak has both low- and high-energy background interferences at $202.1 \mathrm{keV}$ and $205.33 \mathrm{keV}$, respectively. Both background interferences cause the ${ }^{239} \mathrm{pu}$ peak to be dramatically reduced in size. This interference is the most significant in that it produces the largest percentage of error (see Figs. 3 to 7 ). The ${ }^{239}$ Pu fraction is the only isotope to be underpredicted with increasing ${ }^{235} \mathrm{U} /{ }^{239} \mathrm{Pu}$. All other isotopes are overpredicted to balance the 1sotopic fractions. The final interference is at $205.33 \mathrm{keV}$, a low-energy background interference with group 7 .

All these interferences contribute to error in either the positive or negative direction, but only the effect of the group 6 background interferences can be seen. Not only do the interferences displace the plutonium isosopic measurements, but also the ${ }^{235} \mathrm{v} /{ }^{239} \mathrm{Pu}$ ratio. This ratio is determined from the 185.7-kev ${ }^{235} \mathrm{u}$ peak and the $203.6-\mathrm{keV}{ }^{239} \mathrm{Pu}$ peak. The background interferences on the ${ }^{239} \mathrm{pu}$ peak cause it to look much smaller, increasing the value of ${ }^{235} \mathrm{v} /{ }^{239} \mathrm{Pu}$. This effect can be observed by studying mox samples of known 
enrichments. Several samples from the Hanford Engineering and Development Laboratory (HEDL) were analyzed with the Cicero MCA. From the known uranium enrichment and isotopics, the actual ${ }^{235} \mathrm{u} /{ }^{239} \mathrm{Pu}$ ratio can be calculated and compared with the cicero value. These data are presented in Table IV. Table IV shows that the ratio of the cicero ${ }^{235} \mathrm{U} /{ }^{239} \mathrm{Pu}$ value to the actual value increases with uranium enrichment. For a standard Mox sample of $80 \%$ uraniun enrichment, the Cicero MCA will. calculate a ${ }^{235} \mathrm{v} /{ }^{239} \mathrm{Pu}$ value approximately two times the actual value.

The ${ }^{240}$ Pu content plays a significant role in the isotopic measurement of both MOX and pure $\mathrm{PuO}_{2}$ samples. Cnly one ${ }^{240} \mathrm{Pu}$ peak $(160.3 \mathrm{keV})$ is available for measurement. For samples having low ${ }^{240} \mathrm{Pu}$ content, short count times may not provide the required statistics for the ${ }^{240} \mathrm{Pu}$ analysis. For pure $\mathrm{PuO}_{2}$ samples, large ${ }^{240} \mathrm{Pu}$ fractions have no effect on the 1sotopic analysis. In MOX samples however, the ${ }^{240} \mathrm{Pu}$ content is related to the magnitude of the relative error: the higher the ${ }^{240} \mathrm{Pu}$ content, the larger the error. Sample 120 has a ${ }^{240} \mathrm{Pu}$ content of $15 \%$ as compared to $11 \%$ for sample 119 . Comparison of the two samples in Fig. 3 shows that the relative error for sample 120 is $20 \%$ higher at a ${ }^{235} \mathrm{U} /{ }^{233} \mathrm{pu}$ ratio of -5 . At lower ${ }^{235} \mathrm{v} /{ }^{239} \mathrm{Pu}$ values, the error is about the same for both samples.

The Cicero MCA Nith tha IAEAPU algorithm would not be acceptable for plutonium isotoplc measurement of highly enriched MOX for IAEA SNM accountability applications. The fissile isotope ${ }^{239} \mathrm{Pu}$ would be underestimated in measurements of highly enriched MOX samples. Two courses of action might solve the

TABLE TV

HEDL MIXED-OXIDE SAFPLES

\begin{tabular}{|c|c|c|c|c|}
\hline \multirow{2}{*}{$\begin{array}{l}\text { Sample } \\
\text { No. } \\
\end{array}$} & \multirow{2}{*}{$\begin{array}{l}\text { Enrichment } \\
(8) \\
\end{array}$} & \multicolumn{2}{|c|}{${ }^{235} \mathrm{v} /{ }^{239} \mathrm{pu}$} & \multirow[b]{2}{*}{ Rat 10 } \\
\hline & & Cicero & Actual & \\
\hline 1939 & 80.2 & 5.8 & 2.77 & 2.1 \\
\hline 1940 & 80.2 & 6.45 & 2.76 & 2.3 \\
\hline 1987 & 30 & 1.34 & 1.09 & 1.3 \\
\hline 2006 & 93 & 8.83 & 3.22 & 2.7 \\
\hline
\end{tabular}


problem. First, the algorithm could be modified to correct for ${ }^{235} \mathrm{U}$ interferences. The code could identify the interferences of significance, determine the peak intensities, and subtract the ${ }^{235} \mathrm{U}$ counts fron the plutonium spectrum. The second course of action would be to use well-established calibration curves to correct the results distorted by the ${ }^{235} \mathrm{U}$ interferences. Curves such as those shown in Figs. 3 to 7 could be used, but caution must be observed. These curves were generated using the ${ }^{235} \mathrm{U} /{ }^{239}$ Pu values calculated by the cicero and therefore incorporate the uncertainty in the ${ }^{235} \mathrm{v} /{ }^{239} \mathrm{Pu}$ ratio. These curves apply only if the cicero-calculated ${ }^{240} \mathrm{Pu}$ content and ${ }^{235} \mathrm{U} /{ }^{239} \mathrm{Pu}$ ratio are used.

\section{REFERENCES}

?. D. Ruhter, "A Portable Microcomputer for the Analysis of Plutoniuin Gamna-Ray Spectra," Vol. I, Lawrence Livermore National Laboratory report UCRL-53506 (1984).

2. H. D. Ruhter, "A Portable Microcompucer for the Analysis of Plutonium Gamma-Ray Spectra," Vol. II, Lawrence ilvermore National Laboratory report UCRL-53506 (1984).

\section{APPENDIX}

DÄPA COLISETION PARAFETERE

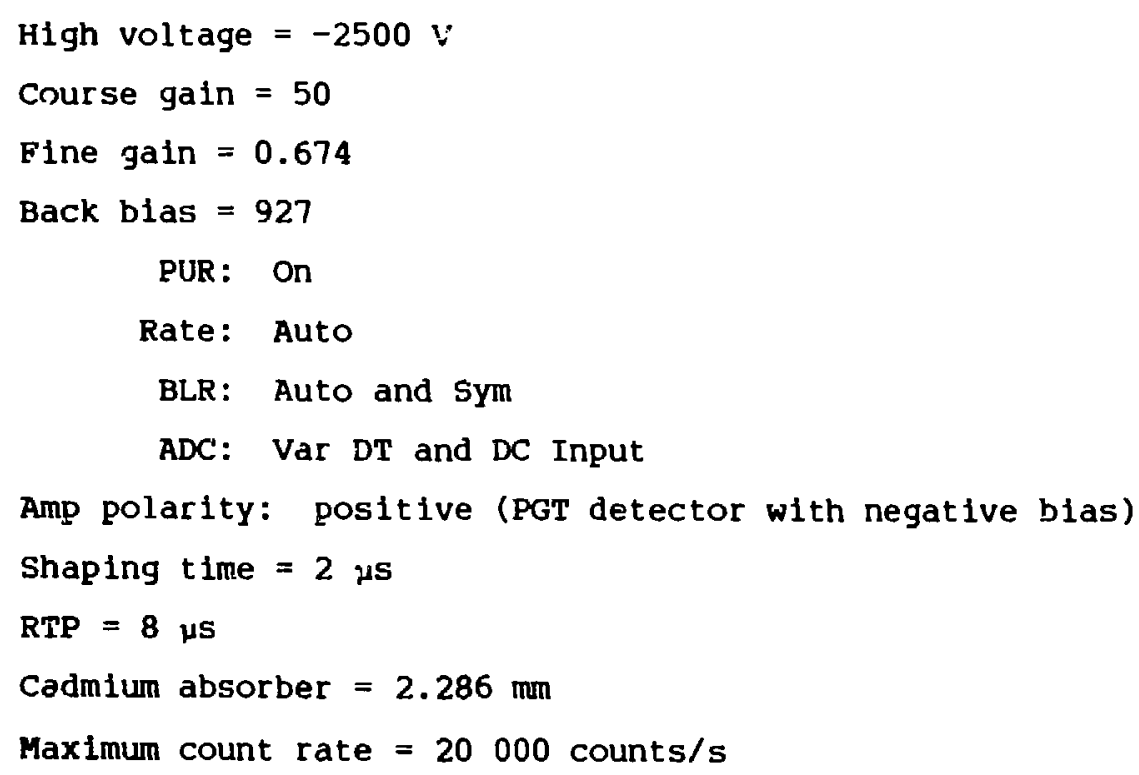

